\title{
Catellibacterium nectariphilum gen. nov., sp. nov., which requires a diffusible compound from a strain related to the genus Sphingomonas for vigorous growth
}

\author{
Yasuhiro Tanaka, ${ }^{1}$ Satoshi Hanada, ${ }^{1}$ Akira Manome, ${ }^{2} \dagger$ \\ Takayasu Tsuchida, ${ }^{2}$ Ryuichiro Kurane, ${ }^{1} \ddagger$ Kazunori Nakamura ${ }^{1}$ \\ and Yoichi Kamagata ${ }^{1}$
}

Correspondence

Satoshi Hanada

s-hanada@aist.go.jp

\author{
${ }^{1}$ Research Institute for Biological Resources and Functions, National Institute of \\ Advanced Industrial Science and Technology (AIST), Central 6, 1-1-1 Higashi, \\ Tsukuba, Ibaraki 305-8566, Japan \\ ${ }^{2}$ Central Research Laboratories of Ajinomoto Co., Inc., 1-1 Suzuki-cho, Kawasaki-ku, Kawasaki, \\ Kanagawa 210-8186, Japan
}

\begin{abstract}
A bacterial strain, designated $\mathrm{AST} 4^{\top}$, was isolated from activated sludge. The bacterium did not show significant growth on nutrient broth, but growth was clearly stimulated by addition of supernatant from other bacterial cultures. Culture filtrate of a strain related to the genus Sphingomonas in particular increased the cell yield and growth rate of strain AST4 ${ }^{\top}$. Phylogenetic analysis based on the $16 \mathrm{~S}$ rRNA gene sequences showed that strain $\mathrm{AST}^{\top}{ }^{\top}$ is located within the 'Rhodobacter group' in the $\alpha-3$ subclass of Proteobacteria, but is clearly distant from related genera in this group such as Paracoccus, Rhodobacter and Rhodovulum. Strain AST4 ${ }^{\top}$ is a Gram-negative, non-motile, rod-shaped $(0 \cdot 6-0.8 \times 1 \cdot 3-2 \cdot 0 \mu \mathrm{m})$ and aerobic bacterium. It was not able to reduce nitrate to nitrite or $\mathrm{N}_{2}$. No phototrophic growth was observed. Optimal growth occurred at $30^{\circ} \mathrm{C}$ and $\mathrm{pH} 6 \cdot 5-7 \cdot 5$. The dominant cellular fatty acid in the isolate was $\mathrm{C}_{18: 1}$ cis11. Ubiquinone-10 was the major respiratory quinone. The $\mathrm{G}+\mathrm{C}$ content was $64.5 \mathrm{~mol} \%$ (by HPLC). Based on the phylogenetic and phenotypic traits, the name Catellibacterium nectariphilum gen. nov., sp. nov. is proposed for this isolate; the type strain is AST4 ${ }^{\top}$ $\left(=\right.$ NBRC $100046^{\top}=$ JCM $11959^{\top}=$ DSM $\left.15620^{\top}\right)$.
\end{abstract}

The majority of micro-organisms distributed in nature are not cultivable by conventional techniques (Amann et al., 1995). One of the primary reasons for such uncultivability is our lack of knowledge about syntrophic relationships between micro-organisms, since some bacterial strains that can not grow on artificial media alone have been cultured in the presence of other bacteria (Ohno et al., 2000; Rhee et al.,

Published online ahead of print on 23 January 2004 as DOI 10.1099/ ijs.0.02750-0.

tPresent address: Kankyo Engineering Corporation, 1 Kimitsu, Kimitsu-shi, Chiba 299-1141, Japan.

‡Present address: Biotechnology Research Centers, KUBOTA Co., Inc., 5-6 Koyodai, Ryugasaki, Ibaraki 301-0852, Japan.

The GenBank/EMBL/DDBJ accession numbers for the 16S rRNA gene sequences of strains $\mathrm{AST}^{\top}$ and GF9 are $\mathrm{AB} 101543$ and AB101552, respectively.

An extended 16S rDNA-based neighbour-joining tree containing all species in the genera Paracoccus, Rhodobacter and Rhodovulum is available as supplementary material in IJSEM Online.
2000; Kaeberlein et al., 2002). To obtain such bacteria, they must be screened with growth factors supplied by the other bacterium. In the course of such an attempt, we isolated a bacterial strain that required a diffusible compound from other bacteria for vigorous growth from an activated sludge. The isolate, designated strain AST4 ${ }^{\mathrm{T}}$, gave weak growth on a nutrient broth, but the growth rate and cell yield were stimulated specifically by the addition of supernatant from a strain related to the genus Sphingomonas. Strain AST4 $^{\mathrm{T}}$ was phylogenetically distant from known bacteria and showed several properties that distinguished it from its other relatives. On the basis of phenotypic and phylogenetic data, we propose that strain AST4 ${ }^{\mathrm{T}}$ belongs to a new genus and species, Catellibacterium nectariphilum gen. nov., sp. nov. The characteristics of this bacterium are described herein.

The novel isolate was obtained by the following procedure. An activated sludge sample $(50 \mu \mathrm{g})$ collected from the Kawasaki plant of Ajinomoto Co. (Japan) was added to $100 \mathrm{ml} \mathrm{NPB}$ medium ( $\mathrm{pH} 7 \cdot 0$ ) (containing $10 \cdot 0$ g tryptone 
peptone, $2.0 \mathrm{~g}$ yeast extract, $1.0 \mathrm{~g} \mathrm{MgSO}_{4} .7 \mathrm{H}_{2} \mathrm{O}, 1.0 \mathrm{~g}$ $\mathrm{K}_{2} \mathrm{HPO}_{4}, 0.5 \mathrm{~g} \mathrm{KH}_{2} \mathrm{PO}_{4}$ and $5.0 \mathrm{~g}$ D-glucose in 11 distilled water) and incubated for 5 days at $30^{\circ} \mathrm{C}$. The resultant culture, which was designated 'bacterial mixed culture', was centrifuged at 15000 r.p.m. for $10 \mathrm{~min}$ and the autoclaved $\left(121^{\circ} \mathrm{C}, 20 \mathrm{~min}\right)$ supernatant was added to NPB medium at a final concentration of $10 \%$. This medium was named NPBCE (NPB containing mixed culture extract) and used as isolation medium for strains requiring growth factors from other bacteria. An aliquot of activated sludge sample diluted to $10^{-4}$ with sterilized water was inoculated on a $1.5 \%$ agar plate. After incubation at $30^{\circ} \mathrm{C}$ for 4 days, colonies that emerged on the agar plates were picked and isolated. The requirement for a bacterial growth factor (or stimulator) supplied by other bacteria by each isolate was verified by comparing growth between the NPBCE agar plate (with the supernatant of bacterial mixed culture) and NPB agar plate (without the supernatant). Consequently, we obtained 30 isolates. Almost all strains did not show significant differences between growth on NPBCE and NPB agar plates. However, one strain, designated strain $\mathrm{AST}^{\mathrm{T}}{ }^{\mathrm{T}}$, showed a clear difference. Although this strain showed weak growth in NPB medium, addition of the supernatant from the bacterial mixed culture markedly increased the growth rate and cell yield (Table 1).

We also tried to refine the NPBCE medium, since it contained the supernatant of bacterial mixed culture, an undefined additive. We searched within the bacterial mixed culture for organisms that could stimulate the growth of strain $\mathrm{AST} 4^{\mathrm{T}}$ alone, and isolated a novel strain, designated GF9. Supernatants prepared from NPB medium culture of strain GF9 greatly elevated the growth yield of strain AST4 ${ }^{\mathrm{T}}$ as well as that of 'bacterial mixed cultures'. The 16S rRNA gene of strain GF9 was partially sequenced (corresponding to positions 912-1389 of Escherichia coli 16S rRNA gene), and the sequence obtained showed $99 \cdot 8$ and $99 \cdot 2 \%$ similarity to those of Sphingomonas adhaesiva (Takeuchi et al., 1994) and Sphingopyxis terrae (Takeuchi et al., 1994). Based on phylogenetic comparison, the strain was considered to be a member of the genus Sphingomonas (Sphingomonas sp. strain GF9). In all cultures of $\mathrm{AST}^{\mathrm{T}}$ for the following tests and analyses, NPB medium supplemented with $10 \%$

Table 1. Growth of strain $A S T 4^{\top}$ in the NPB and NPBCE medium

Cells were grown in $5 \mathrm{ml}$ of each medium at $30^{\circ} \mathrm{C}$ with shaking (160 r.p.m.). Growth was measured as $\mathrm{OD}_{660}$. Standard deviations are shown in parentheses $(n=3)$.

\begin{tabular}{|lcccc|}
\hline \multirow{2}{*}{ Medium } & \multicolumn{4}{c|}{ Growth of strain AST4 ${ }^{\mathbf{T}}$} \\
\cline { 2 - 5 } & 1 day & 2 days & 3 days & 4 days \\
\hline NPB & $0 \cdot 05(0 \cdot 01)$ & $0 \cdot 13(0 \cdot 01)$ & $0 \cdot 25(0 \cdot 01)$ & $0 \cdot 37(0 \cdot 01)$ \\
NPBCE & $0 \cdot 29(0 \cdot 03)$ & $0 \cdot 91(0 \cdot 02)$ & $1 \cdot 01(0 \cdot 02)$ & $0 \cdot 98(0 \cdot 01)$ \\
\hline
\end{tabular}

supernatant from stationary-phase Sphingomonas sp. strain GF9 (NPBGF9 medium) was used.

The morphological, physiological and phylogenetic characteristics of strain $\mathrm{AST}_{4}^{\mathrm{T}}$ were investigated. The strain formed smooth, circular, white to beige colonies on $1.5 \%$ agar plates after $36-48 \mathrm{~h}$ incubation at $30^{\circ} \mathrm{C}$. The size, shape and ultrastructure of the cells were examined by phasecontrast microscopy and transmission electron microscopy (Fig. 1). Cells of strain AST4 ${ }^{\mathrm{T}}$ were non-motile, Gramnegative and ovoid to rod-shaped, $1 \cdot 3-2 \cdot 0 \mu \mathrm{m}$ long and $0 \cdot 6-0 \cdot 8 \mu \mathrm{m}$ wide. Formation of pairs or chains of cells was


Fig. 1. Phase-contrast photomicrograph (a; bar, $10 \mu \mathrm{m})$ and electron micrograph of ultrathin section ( $b$; bar, $0.5 \mu \mathrm{m}$ ) of cells of strain AST4 ${ }^{\mathrm{T}}$. Cells were grown on NPBGF9 medium at $30{ }^{\circ} \mathrm{C}$ for $24 \mathrm{~h}$. For transmission electron microscopy, a highpressure freezing method (Yamaguchi et al., 2002) was used. After freeze-substitution, ultrathin sections of the sample were prepared as described previously (Hanada et al., 2002). Samples were stained with uranyl acetate and lead citrate and examined with a Hitachi H-7000 transmission electron microscope. 
frequently observed. Since cells tended to remain attached to the chains, cell aggregates were usually formed in liquid medium. An electron micrograph of a thin section revealed that the isolate has the typical Gram-negative cell-wall structure with an outer membrane and very thin murein layer. Cells did not contain any type of intracytoplasmic membrane. Spherical accumulations of intracellular material were frequently observed and the material was identified as polyhydroxybutyrate by a method using Sudan black B (Jenkins et al., 1993). These storage granules (about $0.3 \mu \mathrm{m}$ in diameter) were also observed in electron micrographs (Fig. 1b). Fibrous structures on the surface of cell, which would be extracellular polysaccharides, were also seen.

Growth of the strain was investigated in liquid cultures and on $1.5 \%$ agar plates. Visible colonies were detectable at $20-37^{\circ} \mathrm{C}$, with optimum growth at $30^{\circ} \mathrm{C}$ on NPBGF9 agar. No growth occurred at 15 or $40^{\circ} \mathrm{C}$. Strain AST4 $4^{\mathrm{T}}$ was able to grow in liquid NPBGF9 between $\mathrm{pH} 6.0$ and 8.0 with optimum growth at $\mathrm{pH} 6 \cdot 5-7 \cdot 5$ (growth was monitored at $\left.\mathrm{OD}_{660}\right)$. When $3 \%(\mathrm{w} / \mathrm{v}) \mathrm{NaCl}$ was added to the liquid medium, no growth occurred. The metabolism of strain $\mathrm{AST}_{4}^{\mathrm{T}}$ was strictly aerobic and it could not grow anaerobically in NPBGF9 medium supplemented with $0 \cdot 2 \% \mathrm{KNO}_{3}$. Neither phototrophic nor fermentative growth occurred. Cytochrome oxidase activity was detected by the method using oxidase-testing paper (Nissui Seiyaku). Catalase activity was positive, as formation of bubbles in a $3 \% \mathrm{H}_{2} \mathrm{O}_{2}$ solution was observed. Physiological tests by API systems (bioMérieux) revealed that the isolate showed the following activities. Neither indole production from tryptophan nor gelatin hydrolysis was observed; reduction of nitrate to nitrite or $\mathrm{N}_{2}$ did not occur; arginine dihydrolase, urease and $\beta$-glucosidase were negative. To test oxidation of various carbon sources in the absence of supernatant from a strain GF9 culture, Biolog GN2 microplates (GSI Creos) were used. The isolate oxidized glycogen, Tween 80 , methyl pyruvate, $\beta$-hydroxybutyrate, $\alpha$-ketoglutarate, DL-lactate, succinate, succinamate, alaninamide, L-glutamate, L-serine and monomethyl succinate as sole carbon and energy sources. Sugars and sugar alcohols such as $\alpha$-D-glucose, D-fructose, D-galactose, D-mannose, sucrose, D-sorbitol, turanose and xylitol were not significantly oxidized.

Quinones, fatty acids and the $\mathrm{G}+\mathrm{C}$ content were analysed by the methods described by Hanada et al. (2002). Strain $\mathrm{AST}^{\mathrm{T}}{ }^{\mathrm{T}}$ contained ubiquinone- 10 as the main respiratory quinone. The major fatty acid in the isolate was $\mathrm{C}_{18: 1}$ cis 11 , which accounted for $91.0 \%$ of total cellular fatty acids. $\mathrm{C}_{17: 0}(3 \cdot 44 \%), \mathrm{C}_{19: 0}$ cyclo11-12 (2·82\%), $\mathrm{C}_{16: 0}(0 \cdot 86 \%)$, $\mathrm{C}_{16: 1}$ cis $\quad(0 \cdot 79 \%), \mathrm{C}_{18: 0} \quad(0 \cdot 72 \%), \mathrm{C}_{17: 0} \quad$ cyclo9-10 $(0 \cdot 21 \%)$ and $\mathrm{C}_{15: 0}(0 \cdot 18 \%)$ were also detected as minor components. No hydroxy fatty acid was detected. The $\mathrm{G}+\mathrm{C}$ content of the DNA of strain AST4 ${ }^{\mathrm{T}}$ was $64 \cdot 5 \mathrm{~mol} \%$ (by HPLC analysis).

An almost complete $16 \mathrm{~S}$ rRNA gene sequence of the isolate was obtained by PCR using two oligonucleotide primers,
5'-AGAGTTTGATCCTGGCTCAG-3' and 5'-GGTTACCTTGTTACGACTT-3' (corresponding to positions 8-27 and 1492-1510 of the E. coli 16S rRNA gene; Weisburg et al., 1991). Phylogenetic analysis of the sequence with the neighbour-joining method (Saitou \& Nei, 1987; Thompson et al., 1994) placed strain $\mathrm{AST}_{4}{ }^{\mathrm{T}}$ within the 'Rhodobacter group' in the $\alpha-3$ subclass of Proteobacteria (Fig. 2; see also the supplementary figure available in IJSEM Online). The isolate was closely related to the genera Paracoccus, Rhodobacter and Rhodovulum. However, strain AST4 $4^{\mathrm{T}}$ was clearly distant from any species in these three genera, with sequence similarities of less than $94 \cdot 7 \%$. These low similarities suggest that the strain differs phylogenetically from related genera and that a new genus should be created for the isolate.

Comparative phenotypic properties of strain $\mathrm{AST}_{4}^{\mathrm{T}}$ and representative genera belonging to the 'Rhodobacter group' in the $\alpha-3$ subclass of Proteobacteria are summarized in Table 2. The strain shared several important characteristics with members of the 'Rhodobacter group'; for example, their quinone component and major cellular fatty acid composition were almost identical. However, the following conspicuous phenotypic traits distinguish the novel isolate from the other three genera: (i) strain $\mathrm{AST}_{4}^{\mathrm{T}}$ was clearly distinguishable from the genera Rhodobacter and Rhodovulum by the absence of photosynthetic activity (Hansen \& Imhoff, 1985; Imhoff, 1989; Hiraishi et al., 1996; Eckersley \& Dow, 1980; Hiraishi \& Ueda, 1994, 1995; Straub et al., 1999), and the isolate could not synthesize photosynthetic pigments (bacteriochlorophylls) under any growth conditions tested; (ii) the isolate did not show nitrate reduction activity, which is typical of most Paracoccus species (13 of 16 members; Kuenen \& Robertson, 1989; Urakami et al., 1989, 1990; Ohara et al., 1990; Katayama et al., 1995; Siller et al., 1996; Lipski et al., 1998; Rainey et al., 1999; Doronina et al., 1998, 2002; Pukall et al., 2003) [the only exceptions are Paracoccus carotinifaciens (Tsubokura et al., 1999), Paracoccus marcusii (Harker et al., 1998) and Paracoccus

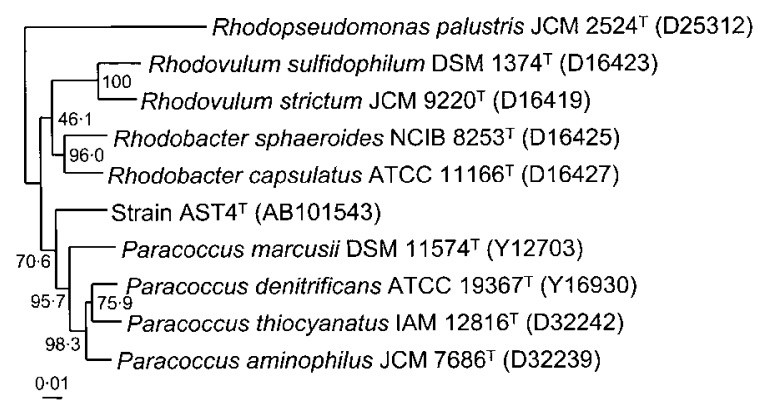

Fig. 2. Phylogenetic tree of strain $A S T 4^{\top}$ and related species based on 16S rRNA gene sequences. Bootstrap percentages are indicated at branching points. Bar, 1 substitution in $100 \mathrm{nt}$. Accession numbers are shown in parentheses. A tree including more reference species is available as supplementary material in IJSEM Online. 
Table 2. Phenotypic characteristics of strain $\mathrm{AST}^{\top}{ }^{\top}$ and related genera

Data for Paracoccus (16 species), Rhodobacter (5 species) and Rhodovulum (6 species) are based on published results. +, Positive; -, negative; $\mathrm{V}$, variable. The quinone system and major fatty acid of strain AST4 ${ }^{\mathrm{T}}$ are $\mathrm{Q}-10$ and $\mathrm{C}_{18: 1}$, which are identical to those of members of the other genera.

\begin{tabular}{|c|c|c|c|c|}
\hline Characteristic & $\mathrm{AST}_{4}^{\mathrm{T}}$ & Paracoccus & Rhodobacter & Rhodovulum \\
\hline Cell shape & Ovoid to rods & Cocci to rods & Ovoid to rods & Ovoid to rods \\
\hline Motility & - & $-{ }^{*}$ & $\mathrm{v} \dagger$ & + \\
\hline Production of carotenoids & - & $-\ddagger$ & + & + \\
\hline Phototrophic growth & - & - & + & + \\
\hline Growth in $3 \%(\mathrm{w} / \mathrm{v}) \mathrm{NaCl}$ & - & $\mathrm{v} \S$ & vll & + \\
\hline Nitrate reduction & - & $+\Phi$ & $\mathrm{V} \#$ & - \\
\hline
\end{tabular}

${ }^{*}$. carotinifaciens and Paracoccus versutus are positive. No data available for Paracoccus alkenifer.

$\dagger$ Rhodobacter capsulatus, Rhodobacter sphaeroides and Rhodobacter azotoformans are motile. Rhodobacter veldkampii and Rhodobacter blastica are non-motile.

$\ddagger P$. carotinifaciens, P. marcusii and P. zeaxanthinifaciens produce large amounts of carotenoids.

$\$$ Paracoccus seriniphilus, Paracoccus denitrificans and P. zeaxanthinifaciens are positive. Paracoccus alcaliphilus, Paracoccus aminophilus and Paracoccus aminovorans give weak growth. Paracoccus solventivorans, Paracoccus methylutens, Paracoccus kondratievae and Paracoccus kocurii are negative. No data for P. alkenifer, P. carotinifaciens, Paracoccus pantotrophus, Paracoccus thiocyanatus or P. versutus.

IIRhodobacter sphaeroides and Rhodobacter azotoformans positive; Rhodobacter capsulatus and Rhodobacter veldkampii negative. No data for Rhodobacter blastica.

S. carotinifaciens, P. marcusii and P. zeaxanthinifaciens are negative.

\#Variable at the strain level.

zeaxanthinifaciens (Berry et al., 2003)]; (iii) it is easy to distinguish the isolate from the three non-nitrate-respiring Paracoccus species because the latter species produce large amounts of carotenoids such as astaxanthin and zeaxanthin, whereas the novel isolate has no ability to synthesize carotenoids.

Based on these phenotypic and phylogenetic comparisons, we conclude that strain AST4 $4^{\mathrm{T}}$ represents a new genus within the $\alpha-3$ subclass of the Proteobacteria, for which we propose the name Catellibacterium nectariphilum gen. nov., sp. nov.

\section{Description of Catellibacterium gen. nov.}

Catellibacterium (Ca.tel.li.bac.te'ri.um. L. n. catella a small chain; N.L. neut. n. bacterium from Gr. n. bakterion a small rod; N.L. neut. n. Catellibacterium a chained small rod).

Gram-negative, strictly aerobic, non-motile, ovoid to rodshaped cells, growing in pairs and chains. No growth under anaerobic conditions either by fermentation, nitrate reduction or phototrophy. Oxidase and catalase are positive. Indole production from tryptophan, nitrate reduction and gelatin hydrolysis are negative. Arginine dihydrolase, urease and $\beta$-glucosidase activities are absent. Intracellular polyhydroxybutyrate accumulation is observed. Growth occurs under mesophilic and neutrophilic conditions. The major cellular fatty acid is $\mathrm{C}_{18: 1}$ cis 11 . DNA $\mathrm{G}+\mathrm{C}$ content of the type strain of the type species is $64.5 \mathrm{~mol} \%$ (by HPLC). Ubiquinone-10 is the major component of the quinone system. 16S rRNA gene sequence analysis places the genus in the $\alpha-3$ subclass of Proteobacteria. The type species is Catellibacterium nectariphilum.

\section{Description of Catellibacterium nectariphilum sp. nov.}

Catellibacterium nectariphilum (nec.ta' ri.phil.um. L. neut. n. nectar nectar; Gr. adj. philos loving; N.L. neut. adj. nectariphilum loving nectar, referring to the stimulation of growth by excretions of other bacteria).

Basic phenotypic characteristics are the same as those described for the genus. Cells are ovoid to rod-shaped $(0 \cdot 6-0 \cdot 8 \times 1 \cdot 3-2 \cdot 0 \mu \mathrm{m})$, occurring in pairs and chains. Colonies are circular and white to beige in colour. The temperature and $\mathrm{pH}$ ranges for growth are $20-37^{\circ} \mathrm{C}$ and $\mathrm{pH} 6 \cdot 0-8 \cdot 0$. Optimum growth occurs at $30^{\circ} \mathrm{C}$ and $\mathrm{pH} 6 \cdot 5-$ $7 \cdot 5$. Glycogen, Tween 80 , methyl pyruvate, $\beta$-hydroxybutyrate, $\alpha$-ketoglutarate, DL-lactate, succinate, succinamate, alaninamide, L-glutamate, L-serine and monomethyl succinate are utilized as sole carbon sources. Diffusible metabolite(s) of other bacteria may be required for vigorous growth.

The type strain is $\mathrm{AST}^{\mathrm{T}} \quad\left(=\mathrm{NBRC} 100046^{\mathrm{T}}=\mathrm{JCM}\right.$ $\left.11959^{\mathrm{T}}=\mathrm{DSM} 15620^{\mathrm{T}}\right)$, which was isolated from an activated sludge sample.

\section{Acknowledgements}

We are very grateful to the following researchers in the Advanced Industrial Science and Technology (AIST): X.-Y. Meng for transmission electron microscopy and M. Muramatsu and A. Sunaga for isoprenoid 
quinone, fatty acid and DNA G + C content analyses. We also would like to thank $\mathrm{Dr} \mathrm{H}$. Zhang for his valuable advice. This study was carried out as a part of the project for NEDO Industrial Technology Researcher in National Institute of AIST.

\section{References}

Amann, R. I., Ludwig, W. \& Schleifer, K. H. (1995). Phylogenetic identification and in situ detection of individual microbial cells without cultivation. Microbiol Rev 59, 143-169.

Berry, A., Janssens, D., Hümbelin, M. \& 10 other authors (2003). Paracoccus zeaxanthinifaciens sp. nov., a zeaxanthin-producing bacterium. Int J Syst Evol Microbiol 53, 231-238.

Doronina, N. V., Trotsenko, Y. A., Krausova, V. I. \& Suzina, N. E. (1998). Paracoccus methylutens sp. nov. - a new aerobic facultatively methylotrophic bacterium utilizing dichloromethane. Syst Appl Microbiol 21, 230-236.

Doronina, N. V., Trotsenko, Y. A., Kuznetzov, B. B. \& Tourova, T. P. (2002). Emended description of Paracoccus kondratievae. Int J Syst Evol Microbiol 52, 679-682.

Eckersley, K. \& Dow, C. S. (1980). Rhodopseudomonas blastica sp. nov.: a member of the Rhodospirillaceae. J Gen Microbiol 119, 465-473.

Hanada, S., Takaichi, S., Matsuura, K. \& Nakamura, K. (2002). Roseiflexus castenholzii gen. nov., sp. nov., a thermophilic, filamentous, photosynthetic bacterium that lacks chlorosomes. Int J Syst Evol Microbiol 52, 187-193.

Hansen, T. A. \& Imhoff, J. F. (1985). Rhodobacter veldkampii, a new species of phototrophic purple nonsulfur bacteria. Int J Syst Bacteriol 35, 115-116.

Harker, M., Hirschberg, J. \& Oren, A. (1998). Paracoccus marcusii sp. nov., an orange Gram-negative coccus. Int J Syst Bacteriol 48, 543-548.

Hiraishi, A. \& Ueda, Y. (1994). Intrageneric structure of the genus Rhodobacter: transfer of Rhodobacter sulfidophilus and related marine species to the genus Rhodovulum gen. nov. Int J Syst Bacteriol 44, 15-23.

Hiraishi, A. \& Ueda, Y. (1995). Isolation and characterization of Rhodovulum strictum sp. nov. and some other purple nonsulfur bacteria from colored blooms in tidal and seawater pools. Int J Syst Bacteriol 45, 319-326.

Hiraishi, A., Muramatsu, K. \& Ueda, Y. (1996). Molecular genetic analyses of Rhodobacter azotoformans sp. nov. and related species of phototrophic bacteria. Syst Appl Microbiol 19, 168-177.

Imhoff, J. F. (1989). Genus Rhodobacter Imhoff, Trüper and Pfennig $1984,342^{\mathrm{VP}}$. In Bergey's Manual of Systematic Bacteriology, vol. 3, pp. 1668-1672. Edited by J. T. Staley, M. P. Bryant, N. Pfennig \& J. G. Holt. Baltimore: Williams \& Wilkins.

Jenkins, D., Richard, M. G. \& Daigger, G. T. (1993). Manual on the Causes and Control of Activated Sludge Bulking and Foaming, 2nd edn. Chelsea, MI: Lewis.

Kaeberlein, T., Lewis, K. \& Epstein, S. S. (2002). Isolating "uncultivable" microorganisms in pure culture in a simulated natural environment. Science 296, 1127-1129.

Katayama, Y., Hiraishi, A. \& Kuraishi, H. (1995). Paracoccus thiocyanatus sp. nov., a new species of thiocyanate-utilizing facultative chemolithotroph, and transfer of Thiobacillus versutus to the genus Paracoccus as Paracoccus versutus comb. nov. with emendation of the genus. Microbiology 141, 1469-1477.

Kuenen, J. G. \& Robertson, L. A. (1989). Genus Thiosphaera Robertson and Kuenen 1984a, $91^{\mathrm{VP}}$. In Bergey's Manual of Systematic
Bacteriology, vol. 3, pp. 1861-1862. Edited by J. T. Staley, M. P. Bryant, N. Pfennig \& J. G. Holt. Baltimore: Williams \& Wilkins.

Lipski, A., Reichert, K., Reuter, B., Spröer, C. \& Altendorf, K. (1998). Identification of bacterial isolates from biofilters as Paracoccus alkenifer sp. nov. and Paracoccus solventivorans with emended description of Paracoccus solventivorans. Int J Syst Bacteriol 48, 529-536.

Ohara, M., Katayama, Y., Tsuzaki, M., Nakamoto, S. \& Kuraishi, H. (1990). Paracoccus kocurii sp. nov., a tetramethylammoniumassimilating bacterium. Int J Syst Bacteriol 40, 292-296.

Ohno, M., Shiratori, H., Park, M.-J. \& 7 other authors (2000). Symbiobacterium thermophilum gen. nov., sp. nov., a symbiotic thermophile that depends on co-culture with a Bacillus strain for growth. Int J Syst Evol Microbiol 50, 1829-1832.

Pukall, R., Laroche, M., Kroppenstedt, R. M., Schumann, P., Stackebrandt, E. \& Ulber, R. (2003). Paracoccus seriniphilus sp. nov., an L-serine-dehydratase-producing coccus isolated from the marine bryozoan Bugula plumosa. Int J Syst Evol Microbiol 53, 443-447.

Rainey, F. A., Kelly, D. P., Stackebrandt, E., Burghardt, J., Hiraishi, A., Katayama, Y. \& Wood, A. P. (1999). A re-evaluation of the taxonomy of Paracoccus denitrificans and a proposal for the combination Paracoccus pantotrophus comb. nov. Int J Syst Bacteriol 49, 645-651.

Rhee, S.-K., Lee, S.-G., Hong, S.-P., Choi, Y.-H., Park, J.-H., Kim, C.-J. \& Sung, M.-H. (2000). A novel microbial interaction: obligate commensalism between a new gram-negative thermophile and a thermophilic Bacillus strain. Extremophiles 4, 131-136.

Saitou, N. \& Nei, M. (1987). The neighbor-joining method: a new method for reconstructing phylogenetic trees. Mol Biol Evol 4, 406-425.

Siller, H., Rainey, F. A., Stackebrandt, E. \& Winter, J. (1996). Isolation and characterization of a new gram-negative, acetonedegrading, nitrate-reducing bacterium from soil, Paracoccus solventivorans sp. nov. Int J Syst Bacteriol 46, 1125-1130.

Straub, K. L., Rainey, F. A. \& Widdel, F. (1999). Rhodovulum iodosum sp. nov. and Rhodovulum robiginosum sp. nov., two new marine phototrophic ferrous-iron-oxidizing purple bacteria. Int $J$ Syst Bacteriol 49, 729-735.

Takeuchi, M., Sawada, H., Oyaizu, H. \& Yokota, A. (1994). Phylogenetic evidence for Sphingomonas and Rhizomonas as nonphotosynthetic members of the alpha- 4 subclass of the Proteobacteria. Int J Syst Bacteriol 44, 308-314.

Thompson, J. D., Higgins, D. G. \& Gibson, T. J. (1994). CLUSTAL W: improving the sensitivity of progressive multiple sequence alignment through sequence weighting, position-specific gap penalties and weight matrix choice. Nucleic Acids Res 22, 4673-4680.

Tsubokura, A., Yoneda, H. \& Mizuta, H. (1999). Paracoccus carotinifaciens sp. nov., a new aerobic Gram-negative astaxanthinproducing bacterium. Int J Syst Bacteriol 49, 277-282.

Urakami, T., Tamaoka, J., Suzuki, K. \& Komagata, K. (1989). Paracoccus alcaliphilus sp. nov., an alkaliphilic and facultatively methylotrophic bacterium. Int J Syst Bacteriol 39, 116-121.

Urakami, T., Araki, H., Oyanagi, H., Suzuki, K. \& Komagata, K. (1990). Paracoccus aminophilus sp. nov. and Paracoccus aminovorans sp. nov., which utilize N,N-dimethylformamide. Int J Syst Bacteriol 40, 287-291.

Weisburg, W. G., Burns, S. M., Pelletier, D. A. \& Lane, D. J. (1991). $16 \mathrm{~S}$ ribosomal DNA amplification for phylogenetic study. J Bacteriol 173, 697-703.

Yamaguchi, M., Biswas, S. K., Kita, S., Aikawa, E. \& Takeo, K. (2002). Electron microscopy of pathogenic yeasts Cryptococcus neoformans and Exophiala dermatitidis by high-pressure freezing. J Electron Microsc 51, 21-27. 